\title{
Problems and Challenges Associated with Value Addition: With Special Reference to Coconut Based Productions in Jaffna District
}

\author{
Sathana, V. ${ }^{1}$ \\ University of Jaffna, Sri Lanka \\ Sathana1976@gmail.com
}

\begin{abstract}
Coconut is one of the major source of Jaffna District. It has the greatest prospects for growth and development. The coconut based producers have been facing huge problems. Value addition in each aspect of coconut based productions create more quality and adequate demand for the products. The purpose of this research is to diagnose the tremendous problems and challenges for value addition of coconut based productions in Jaffna District. Initially this paper reviewed the existing literature, empirical studies as well as the prevailing data bases in order to identify the problems and challenges for value addition. Then researcher conducted qualitative exploratory narrative research on coconut based productions in Jaffna District. Subjects were the owners or managers of enterprises and purposive sampling technique was utilized to select the subjects for this research. Unstructured interview was conducted to collect data. The problems and challenges of entrepreneurs regarding value addition were categorized with coding method by using NVIVO software. Present study identified two types of problems; internal and external problems associated with value addition. This research had two coin side implication, for owners of enterprises and other stakeholder to improve the productivity of organizations.
\end{abstract}

Keywords: Value Addition, Problems and Challenges, Coconut based Production

\section{Introduction}

Nowadays sustainability of business is questionable and challengeable. The sustainability covers the wide area such as facing the competitive environment, protecting the green environment and social well_ beings. Small and Medium Enterprises (SMEs) are the prime business sectors in Sri Lanka. The Government of Sri Lanka recognizes SMEs as the backbone of the economy, as it accounts for more than $75 \%$ of the total number of enterprises, provides

${ }^{1}$ https://orcid.org/0000-0001-6914-5708

Kelaniya Journal of Management | 2017 | Special Issue | Page 24 
$45 \%$ of the employment and contributes to $52 \%$ of the Gross Domestic Production (National policy Framework for SME Development, 2015). Local war created huge unbelievable marks for the Jaffna District. SMEs in Jaffna District have been recovering from the war wounds. There are many efforts to reconstruct and rehabilitate the school, banks, roads, power and energy and other key infrastructure in Jaffna District. Most of the producers in Jaffna district are facing huge problems, and they are unable to manage the problems and ultimately left from the businesses. Coconut is the one of the major raw material source and part of SMEs in Jaffna district. Most of the coconut plants were destroyed in the war time and after the war they were replanted. Coconut fiber and coconut based productions have high demand in local, national and international market and further they are very environmental friendly products, hence this sector has high opportunity to grow. At the same time coconut based productions are in the embryonic stage and haven't essential quality and differentiation in Jaffna district, they can't compete with the national and international brands and prices. There is essential to improve value of coconut based products. Coconut based producers have been facing huge problems and challenges for value addition of products. It is essential to identify the problem and challenges associated with value addition. Then it will help to create proper strategies to rectify problems and compete with the national and international brands. Any research has not been conducted regarding the identification of problems and challenges associated with the coconut based production in Jaffna district. This purpose of this paper is to identify the major problems and challenges associated with the coconut based productions in Jaffna district.

\section{Significance of the Study}

SMEs play a vital role for the blossoming development of the nation and they are significant forces in world economy. Poverty and employment are the persisting problems in those economies in developing countries. SME sector of Sri Lanka has not achieved desired level of contribution when compared with other developed and developing countries (Gamage, 2003). Coconut based productions are major part of SMEs. Particularly coconut coir and coir based production is considered as specific economic activity of manufacturing industry (Economic Census, 2013/2014). Despite Sri Lanka being the best source of coir in the world, this valuable resource is still underutilized as local coir mills estimated to be processing only a fraction of available husks (Economic Census, 2013/2014). 
Coconut is the major plantation in Sri Lanka, particularly in prewar environment in Jaffna district. Coconut fiber and coconut based productions have high demand in national and international level. There is very good nature and environment for the coconut plantation in Jaffna district. Export data shows the increasing trend of export of coconut based productions over the eight years. The top 10 districts on ranking were listed, Kurunegala, Matara and Gampaha were first three (Economic Census, 2013/2014), but Jaffna districts was not fallen in any significant position. Even though coconut is the major plantation, its productions have not been getting any important contribution. This low contribution displays that the problematic situation in the value addition of coconut based productions. So it is essential to study this problems and it will help to produce suitable value addition models, which will leads to the development of post war Jaffna district, increase income, and reduce poverty and ultimately growth and development of nation. Further there are multi-faceted opportunities prevailing in the coconut based sector, they are: promoting balanced regional development, improvement in the overall investment climate and foreign direct investment and promoting this sector offers huge employment opportunities.

\section{Literature Review}

\section{Value Addition}

Porter (1985, p. 3) defined value as "what buyers are willing to pay". By adopting either a cost leadership or a differentiation strategy, firms create value for their customers by either lowering their costs or raising their performance. Kotler, Keller \& Lu (2009) produce five product level, explains the value that consumers attach to a product. The organizations consider what its "core" and "non- core" elements to allocate resource. The customer are satisfied when the specified value is identical or higher than the expected value. Naumann and Giel (1995) defined value as meeting or exceeding customers' expectations in product quality, service quality and value-based prices. Value is the relative worth of a product based on utility and importance to the buyer, it attract buyer and create awareness and interest. It is delivered by the product itself and how it meets the buyer's current needs. Adding value is expected in the course of regular business, and it takes many forms like customer incentives, no-cost options, loyalty programs and giveaways. It involves taking something with a value and adding it on for the buyer. That is extra features that go beyond the standard product offering. Business magnifies buyer desire and may lead to action. It is delivered by the seller's company as a marketing tool to incentivize 
buyers add to gain a competitive edge. Creating value goes further. It requires identifying what would be of value to an individual buyer and then finding or making a way for that unique value to be realized. Unlike added value, created value is original and unique to the one buyer it suits (Deb Calvert, 2013).

The traditional role of added value was to distinguish brands from commodities (De Chernatony, Harris, \& Dall'Olmo Riley, 2000). Later a more competitive framework emerged, stressing superior customer value through operational excellence, customer intimacy or product leadership (Treacy \& Wiersima, 1993). The focus also shifted to the processes that enable organizations to deliver superior customer value (Slater \& Narver, 1994). Added value thus moved from being a means for differentiating an offer to a basis for choice, by means of cues that enable customers to recognize superior value and be more confident in their choice (Bloom \& Reve, 1990; Schmitt \& Simonson, 1997). Product innovation no longer offers sufficient competitive advantage in differentiating successful companies (McGrath, \& O'Toole, 2011). Competitors are quickly able to copy innovations, product life cycles are becoming shorter and competitors from low wage countries have considerable cost and price advantages. At the same time, Information and Communication Technologies (ICTs), offer unprecedented opportunities to rearrange value creation activities in new and different ways (Teece, 2010).

Value added is the creation of a competitive advantage by bundling, combining, or packaging features and benefits that result in greater customer acceptance (Grace \& Fridah, 2016). Valueadded describes the enhancement a company gives its product or service before offering the product to customers. Finding out what the customer truly values is critical to how the company produces, packages, markets and delivers its products. Value is added or created in different ways as strong branding, superior service and additional features and benefits and Build and enhance proficiencies in Excel for finance (Grace \& Fridah, 2016).

Value addition is the process of changing the product's value by changing its current place, time and form characteristics to characteristics more preferred in the market place. Adding value to products can be accomplished in a number of different ways, but generally fall into two main types: innovation and coordination (De Chernatony, Harris \& Dall'olmo Riley, 2000). In general, the problem is to evaluate what, where, how and who can efficiently perform the marketing functions. Innovation focuses on improving existing processes, products and services or creating new ones. Innovation also can come from research about alternative 
product or services. The value addition has been widely advocated as a strategy for achieving competitive advantage in an increasingly hostile commercial environment and creating customer value (Nagarajan, Mohanty, \& Misra, 2013). Value addition is bundling, combining, or packaging features and benefits that result in greater customer acceptance. Further it is packaging, services, advertising, advice, delivery arrangements and other things that can be of value to consumers". It is extreme packaging, surprising advertisements, customer-oriented service and affordable payment terms. Porter (1985) suggested that activities within an organization add value to the service and products that the organization produces, and all these activities should be run at optimum level if the organization is to gain any real competitive advantage.

\section{Coconut based productions}

Coconut is one of the major plantation crops in Sri Lanka, which accounts for approximately $12 \%$ of the country's agricultural produce. The total land area under cultivation is 395,000 hectares and about 2,500 million nuts are produced per year. Sri Lanka is in the fourth position among the other coconut producing countries in the world (EDB, 2015). The three major coconut product sectors are coconut kernel products, fiber products and shell products. Coconut kernel products are desiccated coconut, coconut cream and milk powder, coconut water and coconut oil. Coconut fiber products are coir twine, doormats, geotextile, and rubberized coir products for horticultural and agricultural industry and coco peat products. Coconut shell product is charcoal. The supply of coir fiber and fiber-based products have been a widespread cottage industry in Sri Lanka for centuries. Government bodies; Coconut development authority, coconut cultivation board and coconut research institute are responsible for product, quality improvement, management, supply development and research respectively (EDB, 2015). Even though, the coir industry is a subsector of "Textile, wearing, apparel, leather, and related products", it is worthwhile to study the industry separately considering its importance to the Sri Lankan economy. Coconut fiber fall into two categories; brown and white fiber, which contribute to $80 \%$ and $20 \%$ respectively. Contribution of Coconut based products is $4.89 \%$ and the average growth rate of exports is $10.45 \%$ between 2007 and 2016 (ESBA, 2011). The SMEs have all played key roles in the transformation of developing to developed countries in Asia. ADB planned to prepare the SMEs sector development program II in Sri Lanka. They identified six sector for strategic growth for development based on the demand conditions. These major SMEs sectors are leather products, fisheries, coconut coir, dairy processing fruits and vegetables and spices. Sri Lanka is the largest supplier of coir in the world market (ADB, 2007). Number of SMEs in Jaffna District 
is 56,279 (Economic census, 2013/2014). According to the records of Industrial development Board, there are 95 coconut based producers in Jaffna District. In which micro producers are 93 and small producers only 2. The coconut based productions in Jaffna District are in very few categories as handmade doormats, fiber brush, broom and coir twine. Coconut fiber of Jaffna district had high demand from national and international level.

\section{Method}

Researcher conducted qualitative exploratory research for exploration of the existing certain phenomena. It analyzes the practices of existing and ideas to the future. This research describes the "subjective reality" of a system; it is the study of a phenomenon. The analysis of embodied lived experience for instance is rooted in phenomenology and phenomenologists forego coding of data all together. Researchers following the interpretive paradigm where the above listed sequential analyses techniques belong to even perceive coding as an abhorrent incompatible act for data analysis. This study was conducted in Jaffna districts in Sri Lanka. The unit of analysis in this study is the managers or owners of the coconut based producers in Jaffna district. There are 95 coconut based producers in Jaffna district from IDB Report.

This research followed the purposive sampling method. The sampling units are owners of the coconut based productions. The detail of coconut producers were collected from Industrial development board. There are fifteen divisions in the Jaffna district. Initially two respondents form each divisions of Jaffna District, then further three and two subjects from Thenmaradchi and Jaffna division respectively. Altogether thirty five owners of coconut based producers are considered for this research to collect data. Under the Primary data collection method, unstructured interviews was conducted for each respondents about thirty to fifty minutes. Already researcher informed to the owners of institutions and got appointments over the phone. Researcher visited to the institution directly and collected information. Further researcher utilized the ideas of previous research to identify the problems (Gamage, 2003; Perera \& Wijesinha, 2011). Secondary data was gathered from Journals, articles in newspapers, books, SMEs publication and reports, central bank reports and publications, and government organizations' data banks and publications.

Narrative research analysis method was employed to diagnose the problems and challenges from study respondents and journals, reports and other publications. Researcher utilized NVivo software of QRS international. Interview was conducted using audio recording, then it 
DOI: http://doi.org/10.4038/kjm.v6i0.7538

was translated and transcribed. After transcription, narratives may be coded according to categories deemed theoretically important by the researcher (Riesman, 1993).Initially the themes were pointed as observed or recorded. Then open code and axial coding were applied to code the data. The open coding is the researcher identification and then second order coding by using Nvivo called as first order coding. Then the axial coding was revealed the themes of second - order from first coding categories. The second order themes were revealed as emergent framework base on Corley and Gioia, 2004. Table 1 displays Nvivo codes and first order, second order and findings respectively in the annexure.

\section{Reliability and Validity}

Researcher utilized NVivo (version 11) to extract subjects' records, transcript and other related document. The validity of this research was presented as five (Silverman and Marvasti, 2008). First the respondent validation, researcher shared the findings with the study subjects and discuss opinion of them regarding the interpretation and credibility of findings. Second refutability was disproved by having diverse subjects to collect the data. Third constant comparison was made by displaying the additional research and expanded data collection to validate emergent findings. Forth under the comprehensive data treatment, researcher examine the data again and again to draw the comprehensive suggestions and conclusions. The fifth deviant-case all interviews was recorded and translated properly without any deviant cases by using NVivo software to manage the data and findings properly.

\section{Findings}

Researcher started interview with the raw material availability for the coconut based productions. The respondents gave answer about raw material:

"I have been producing coconut fiber, I have high demand but I can't get enough raw material"

"Salt water is good for the quality raw material of fiber but we haven't salt water, it is only available near to seashore or we want to use huge amount of salt, it will be cost"

From the reports of coconut cultivation board:

"The existing coconut cultivated land and newly plated land. The report says that there will be sufficiency of raw materials in year 2000". 
DOI: http://doi.org/10.4038/kjm.v6i0.7538

Another important question regarding the quality of products, the subjects gave answer:

“We manually produce traditional productions, few categories, haven't any differentiation and we try to sell to local shops"

"I can produce different product but it will take more time to produce manually"

"I have machine and can produce different types and categories but I don't know how I can get quality accreditation"

From the information of coconut cultivation board:

"We haven't coconut development authority to facilitate research and development and quality accreditation in Jaffna district”,

Based on the problematic situation of coconut producers, the experiences were discussed, then the problems were compared with the researchers, reports and publications and finally result and discussion were made.

\section{Result and Discussion}

In discussing the questions, subjects have given most valuable information of this study. The problems and challenges associated with value additions are divided into two categories: internal problems and external problems. Internal problems are:

a. In adequate raw material: according to the data from coconut cultivation board land usage for the coconut plantation was 12480ac, but the damaged land area in the war time 6125 ac, new plantation of coconut was 13410 ac in 2015 . Now the raw material are inadequate for demand.

b. Traditional based Production and high cost: Most of the productions are in traditional based method and no any innovative or creative production method, poor quality, poor packaging, poor diversification in products, low amount and high cost.

c. Poor Layout and factory facilities: the production process needs some essential requirements to have high quality products. They are wet coconut husk, salt water, adequate place to prepare raw materials, separate building facilities for every process with proper layout, working condition, safety equipment and dresses are very problematic and poor condition. 
d. In adequate machineries: coconut based producers have high demand for coconut fiber, mostly manual based productions and they haven't adequate machineries for the innovative and quality productions.

e. Inadequate Capital : machineries for the productions are very cost full, the micro producers unable to spends money on purchase of essential machineries

f. Poor education and attitudes of entrepreneur: educated people reluctant to involve in the entrepreneurship, most of the producers are uneducated, Most of the entrepreneurs have negative attitude regarding their growth and development, and they are risk avoiders, easy earning expectation and not future perspective thinking.

g. Poor technology: producers have been using only traditional productions, innovative technology is not used for differentiation or quality products.

h. No market research: no market research regarding demand for the products, producer haven't any research on consumers about their needs, wants and preferences. They produce what they can and try to sell.

i. No competitive analysis: coconut producers haven't any competitive analysis, that is competitors' details regarding products, prices, product differentiation etc.

j. No innovative marketing: the production are sold to only local customers, these customers are middle and low income people.

k. Labor availability: it is very hard to get the labor, because producers only pays low wages, and high labor turn over, inadequate working condition and poor safety are harm to labors.

1. Entrepreneurs and employees knowledge and experience: even though the machineries are equipped for the productions, labors are not trained well, and leave from work. Education, professional qualification and IT knowledge of Micro entrepreneur is very low. Media awareness, web, internet, networking knowledge is very poor to entrepreneurs and employees in Jaffna District. Workload for employees is high, high absenteeism and labor turnover are high.

External problems for coconut producers are:

a. Political and Legal problems: According to answer of the respondents political challenges are instability in development policy over the period of time, poor legal literacy, labor low barriers regarding EPF and ETF, undefined wag level for employees, approval of patent copyright and quality standards in Jaffna district, poor compensation to displaced entrepreneur to restart or recover from post war situation, , restriction to get the loan, 
political vulnerability, no separate tax system to war affected Jaffna District, many procedure for registration of business, child labor law restriction and inadequate fund allocation and consideration for research and development sector by government. Further huge area of usable land is in the hand of government after the local war. There is high requirement to get quality standard as GMP (Goods manufacturing process), SLS (Sri Lanka Standard) and ISO (International standard organization).

b. Economic and Socio cultural challenges: The most of the entrepreneurs are facing financial difficulties. The entrepreneurs are poor financial literacy regarding loan utilizations and loan repayment, favorable loan scheme but in practice many documentary and guarantee requirements. Further increasing inflation leads to high labor cost, raw material and other cost, high cost of production, low margin, increase in price, and decrease in demands for products. There is very poor media assistances, high advertising cost, and Limited working capital to coconut producers. There is no gender based equality in salary and also in type of works in SMEs. Males are dominant mostly as entrepreneur in higher position and women are assisting to them. Mobility to get raw material and market access are limited to women.

c. Technological problems: Coconut producers in Jaffna district are technology back, lack of innovated machinery, mostly manual based productions. Most of SMEs have traditional based productions, and no Nano technology adoptions. Further they haven't upgraded technology, web based e- marketing, social network marketing system and poor media support to convey the proper message to producers.

d. Green environmental problems: The entrepreneurs in Jaffna district are struggling problems with environmental certification regarding air, emission, noise and vibration, waste water and solid waste, environment balance, occupational safety and health, greener production inducement, organic productions and raw material exploitation. Coconut producers have to be certified under stringent food safety, quality management, environmental management, health and safety and social accountability standards. The consumers are not knowledgeable and poor health conscious to consume healthy, organic and greener products.

e. Competitive problems: The entrepreneurs are in embryonic stage in Jaffna district, manual productions, having poor quality, finishing and packaging, poor diversification of products, low output, no efficient and effective productions, no economies of scale, low consumer switching cost, only short term market success, questionable survival, poor research and development, high energy cost, no any market research to identify the 
consumers' needs, wants, styles and new trends properly, internally inadequate strength, risk avoiding manner of entrepreneur, no innovated technology adoption and poor media awareness and reach. SMEs are in weak position to compete locally, nationally and internationally.

\section{Conclusion and Recommendation}

The study revealed that coconut producers have been facing huge problems and challenges for the value addition. Present study identified two types of problems; internal and external problems. The internal problems for value addition are: inadequate raw material, traditional based production and high cost, layout and factory facilities, inadequate machineries, inadequate capital, poor education and knowledge of entrepreneurs, poor attitude of entrepreneurs to develop, poor technology, no market research, consumer research and competitive analysis, inadequate labor, unskilled labor to handle innovative technology. External problems are: political, legal, economic, social, cultural, technological, environmental, and competitive problems. Export databases shows that there are high demand for the coconut fiber and other products. The national demand for this product is also high. Now emerging issues of environmental problems are dissolved by this econ friendly coconut based product. So high prospect and huge problems of coconut based productions create more challenge to win the situation.

There are huge level unutilized land for coconut cultivation in Jaffna district. Last 30 years SMEs in Jaffna district sustained unforgettable wounds by local war, it is very hard to pull up and bring them to a smooth successive level. With their bad experience, all entrepreneur can only think about short term, they can't think about long term and sustainability. First they want to realize that they are in safety and good prospected environment, it is very important to create self-confidence, positive attitude and challenging and risk taking habits. Then only they will involve successfully in their production or business. That is a big bridge building programs. Government must allocate more money to science and technology and research and development. The fiber extracted from the "Mesocrap" the outer layer of the coconut, coir fiber, enjoy the unique properties of being the longest, natural fiber as well as the strongest in terms of twist resistance. The unique technique known as "drum system", it is mostly suitable for brush industry. Any one in Jaffna district hasn't utilized this technology. This technology is the major part of value addition. But this technology wants huge investment and trained staff. So collaborative work of government, nongovernment, university and entrepreneurs are very 
DOI: http://doi.org/10.4038/kjm.v6i0.7538

important for the long term sustainable development of coconut based productions. Furthermore standardization of educational or professional qualification and wage or salary level to employees creates more strength concrete to the development of entrepreneurs. Now a days Media is power full tool to convey the information to public, hence print Medias must plan to allocate reasonable page and telecast and broadcast media must allocate a particular time to convey the information regarding the coconut products. Infrastructure development like information technology, harbor, airport and low cost energy energize smooth operations and supply chain to the coconut based productions. Coconut oil is healthy product and also have high demand. All these awesome suggestions for the coconut sector are envisaged the opportunities to contribute for transforming lagging regions into emerging regions of prosperity.

\section{Implication of the Research}

Value addition is essential for the coconut based productions in Jaffna district to compete and survive in the dynamic environment. Identification of problem and challenges associated with the value addition is essential to create strategies manage the challenges of unpredictable environment. This research has two coin side implication, for owners of enterprises and other stakeholder to improve the productivity of organizations. Properly identified problems can help in the ways to create proper value addition strategies to increase quality of product, differentiate the product from competitors, adopt new technologies for their marketing mix, create proper layout and factory facilities and ultimately positive attitude to grow and develop the production. Other stakeholders can identify the problems which were barrier for the improvements, creating financial availability, research institutions, innovated technology based production, training, consultation to change the attitude and market opportunities. Internal organizations properly rectify these problems with the assistance and collaboration of all stakeholder of coconut based proactive institutions. Further based on these identified problems it essential to create proper value addition strategies in future research. 
DOI: http://doi.org/10.4038/kjm.v6i0.7538

Appendix: Data analysis by using Nvivo

Table 1: Nvivo codes, first- order categories and second order themes

\begin{tabular}{|l|l|l|l|}
\hline In vivo codes & First order categories & $\begin{array}{l}\text { Second order } \\
\text { theme }\end{array}$ & Final Coding \\
\hline $\begin{array}{l}\text { Most of the productions are in } \\
\text { traditional based method and no any } \\
\text { innovative or creative production } \\
\text { method, poor quality, poor } \\
\text { packaging, poor diversification in } \\
\text { products, low amount and high cost. } \\
\text { productions, old types of } \\
\text { products }\end{array}$ & $\begin{array}{l}\text { production, old } \\
\text { methods and } \\
\text { products }\end{array}$ & $\begin{array}{l}\text { based } \\
\text { production and } \\
\text { high cost }\end{array}$ \\
$\begin{array}{l}\text { The production process needs some } \\
\text { essential requirements to have high } \\
\text { quality products. Wet coconut husk, } \\
\text { salt water, adequate place to prepare } \\
\text { quality raw materials, separate } \\
\text { building facilities for every process } \\
\text { with proper layout, working } \\
\text { condition, safety equipment and } \\
\text { dresses are very problematic and } \\
\text { poor condition }\end{array}$ & no safety procedures and & $\begin{array}{l}\text { Poor working } \\
\text { condition and } \\
\text { layout of } \\
\text { organization }\end{array}$ & Poor Layout and \\
factory facilities \\
\end{tabular}

\section{References}

ADB. (2007). Sri Lanka: preparing the small and medium enterprises sector development program II. Technical Assistance Consulting's report, Ministry of Finance and planning, government of Sri Lanka.

Bloom, P. N., \& Reve, T. (1990). Transmitting signals to consumers for competitive advantage. Business Horizons, 33(4), 58-66. https://doi.org/10.1016/0007-6813(90)90059$\underline{\mathrm{K}}$

Corley, K. G., \& Gioia, D. A. (2004). Identity ambiguity and change in the wake of a corporate spin-off. Administrative science quarterly, 49(2), 173-208. 
DOI: http://doi.org/10.4038/kjm.v6i0.7538

Crals, E., \& Vereeck, L. (2005). The affordability of sustainable entrepreneurship certification for SMEs. The International Journal of Sustainable Development \& World Ecology, 12(2), 173-183. https://doi.org/10.1080/13504500509469628

De Chernatony, L., Harris, F., \& Dall'Olmo Riley, F. (2000). Added value: its nature, roles and sustainability. European Journal of marketing, 34(1/2), 39-56. https://doi.org/10.1108/03090560010306197

Deb Calvert. (2013). Value, Value Added and Value Creation, Sales \& Business Development. Retrieved from http://www.managingamericans.com.

Economic Census, 2013/2014. Department Of Census and Statistics Ministry of Policy Planning Economic Affairs, Child Youth and Cultural Affairs.

EDB. (2015). Coconut and coconut based products from Sri Lanka. Retrieved from http://www.srilankabusiness.com.

ESBA. (2011). Micro and small Business in the EU. European Export performance indicators of Sri Lanka 2007-2016, Sri Lanka Export development board.

Gamage, A. S. (2003). Small and Medium Enterprise Development in Sri Lanka: A Review. Meijo University, Faculty of Business Management, Nagoya, Japan.

Grace.S.T \& Fridah,T. (2016). Factors Affecting Value Addition to Tea by Buyers within the Kenyan Tea Trade Value Chain, International Journal of Humanities Social Sciences and Education (IJHSSE), 3(2), 133-142

Kotler, P., \& Keller, K. (2012). Marketing management, $14^{\text {th }}$ edition, Prentice Hall.

Kotler, P., Keller, K. L., \& Lu, T. (2009). Marketing management in China. Prentice Hall.

McGrath, H., \& O'Toole, T. (2011). Challenges in implementing the markets-as-networks approach to marketing for SMEs. Irish Marketing Review, 21(1/2), 58.

Nagarajan, V., Mohanty, A. K., \&Misra, M. (2013). Sustainable Green Composites: Value Addition to Agricultural Residues and Perennial Grasses. ACS Sustainable Chemistry \& Engineering, 1(3), 325-333. https://doi: 10.1021/sc300084z

Naumann, E., \& Giel, K. (1995). Customer satisfaction measurement and management: Using the voice of the customer. Van Nostrand Reinhold. 
DOI: http://doi.org/10.4038/kjm.v6i0.7538

Perera. D and Wijesinha. A (2011), SME Development Strategies for Sri Lanka: Learning Lessons from Neighboring Countries. Retrieved from http://www.ips.lk/

Porter, M.E. (1985), Competitive Advantage: Creating and Sustaining Competitive Advantage, Free Press, New York, NY.

Riesman, C. K. (1993). Qualitative research methods series: Narrative analysis.

Schmitt, B., \& Simonson, A. (1997). Marketing aesthetics: The strategic management of brands, identity, and image. Free Press.

Silverman, D., \& Marvasti, A. (2008). Doing qualitative research: a comprehensive research: a comprehensive guide. Thousand Oaks, CA: Sage

Slater, S. F., \& Narver, J. C. (1994). Market orientation, customer value, and superior performance. Business horizons, 37(2), 22-28.https://doi.org/10.1016/0007$\underline{6813(94) 90029-9}$

Teece, D. J. (2010). Business models, business strategy and innovation. Long range planning, 43(2), 172-194. https://doi.org/10.1016/j.lrp.2009.07.003

Treacy, M., \& Wiersema, F. (1993). Customer intimacy and other value disciplines. Harvard business review, 71(1), 84-93. 